\title{
Family Counseling in Malaysia: Current Issues and Practices
}

\author{
Norhayati Mohd. Noor ${ }^{1}$ \\ ${ }^{1}$ Faculty of Education, Universiti Kebangsaan Malaysia, Malaysia \\ Correspondence: Norhayati Mohd. Noor, Faculty of Education, Universiti Kebangsaan Malaysia, 43600 UKM \\ Bangi, Selangor, Malaysia. Tel: 603-8921-6233. E-mail: norhayati@ukm.edu.my
}

Received: July 22, 2014 Accepted: November 5, 2014 Online Published: December 21, 2014

doi:10.5539/ies.v7n13p33 URL: http://dx.doi.org/10.5539/ies.v7n13p33

\begin{abstract}
The study is carried out to explore the issues and practices in family counselling among the family counsellors at few counseling centres in Malaysia. Qualitative approach of single case embedded units was used for the study. Data collection was done using in-depth interview, observation and document analysis with 12 family counsellors. The data collected from these interviews, observation and document analysis then analysed using Nvivo 8. The analysis highlighted themes like children issue, family involvement, competency of the counsellors and the use of individual theories. The study also shows that the family counselling prefer to use and focus on the individual counselling and not the system. Therefore training for the counsellors who are practising family counselling should be improved by relevant parties. Family perception that child as the individual who is the root of the problem (inditied patient) in the family should be erased from our thoughts. Family awareness that family counselling intervention is vital in strengthening the family institution and it is a needed intervention in developing excellent generation of Malaysians as announced by relevant parties for family development in Malaysia.
\end{abstract}

Keywords: Malaysia, family, family counselling, counselling, current issues, current practices

\section{Introduction}

In Malaysia, family counselling in community counseling is needed in order to boost personal development and harmony of all individuals and community (Ahmad, 2007). Family counselling is a process to encourage family growth, instill mental health and good communication (Salim, 2006). In family counselling every family member has the opportunity to voice out their problem and dissatisfaction towards their problem (Ismail, 2000). Therefore the problem needs professional help from relevant agencies in the community and professional counsellors.

Family counselling abroad able to increase the competitiveness of a family, improve the students' misbehavior and help in their healing process (Milliren \& Barrett-Kruse, 2002; Keith, 2001; Herbert, 1989). Besides, family counselling should focus on how to tackle children with disabilities, special needs and the clever ones. Therefore family counselling is offered actively at all settings like school, hospital, community centres. Stinchfield (2004) did a study on how family counselling is done at home and gave positive impact on family harmony. On the other hand, family counselling in Malaysia is offered by government agencies like Ministry of Women, Family and Community Development, state religious agencies (especially Negeri Sembilan) and NGOs. Meanwhile in school, family counselling is stated being offered but there is no record or document on how it is actually being implemented.

Like in the West or other Asian countries, the need for family counselling is high in Malaysia and demanding by the community in handling all sorts of issues and challenges in a family (Rozman et al., 2003). Therefore, the increase of services for family counselling, prefessional counsellors in family counselling and community centres for family counselling is not something that can be taken lightly. Services that are family based like family counselling are much needed and to be offered widely. Nowadays the Malaysian community is open to the approach of counselling in handling social problems thus it is possible that family counselling can be a primer need for the society in Malaysia especially in handling varieties of social issues and mental health.

Lew and Bettner (1999) stated that a family does not only need family counselling when there is a major crisis, but minor ones do require similar attention like unable to apply positive attitude for a family member. According to him, although there is one family member who misbehaves, the effect is huge enough for the whole family. 
Suradi (2006) supported this by saying that family counselling is useful in:

Handling increasing problem of a family member or more who influence children's problem, anger or depression of a parent.

Handling changes in family or relationship like divorce or a child leaving home.

Handling cultural sexual conflict and inter cultural between family and community at large.

Discovering satisfaction in relationship.

In Malaysia, studies related to family couselling are minimal. However there is a relevant study done by Saedah Ghani 2004 entitled effect of family counselling on family adjustment, cohesion, problematic behavioral environment and early independence of problematic teenagers. The purpose of the study is to test the effectiveness of family counselling in handling the issues of problematic teenagers and improving on the independence issue, family adjustment, cohesion and environment. The researcher used experimental design to observe the effectiveness of family counselling. In the study, the researcher compared the individual counselling in family and the family counselling with systematic approach. The result shows that the family counselling is more effective than individual counselling in solving family problems. In order to solidify the past studies, the present study is carried out to highlight the issues and practices in family counselling.

\section{Methodology}

The study is a case study that explores practices of counsellors who are active players in family counselling with the pursuit of strong family ties. Qualitative approach through few data collection techniques are done in looking at the phenomenon of counsellors' practices in counselling sessions from the start until the end. Collection of data was done through interview, observation and document analysis as usually carried out by qualitative researcher, with 12 family counsellors. Data from the interview was transcribed in verbatim form by the researcher and 2 assistants of counselling undergraduates. Transcript in verbatim form was shown again to the participants for verification and validity. Data from the observation was not transcribed but the researcher made a check list for the observation. According to Pratt and Dolbin-MacNab (2003), not all data in qualitative research need to be transcribed; only the main data needs to be transcribed. Support data or data for triangulation does not need to be transcribed. The researcher used NVivo8 as a tool to organize the transcribed data. Using themes and sub themes, the researcher managed to study the transcript inductively and deductively repeatedly (Merriam, 2009). The researcher was able to apply the relevant theories and literature review to ease the understanding process of the verbatim and give ideas on constructing the sub themes.

\section{Research Findings}

In the study, the themes that are related to the issues and practices in family counselling are children issues, the use of individual theories in family counselling and the techniques used in the practices of family counselling by counsellors in Malaysia.

\section{Issues in Family Counselling}

Research findings show that the children issues are the most popular one in a family counselling session. The children issues that often highlighted in the sessions are school truancy, studies problem, theft, drug addiction, smoking, illegitimate pregnancies, rape, loitering, running away from home, social ills and deviant behaviour. According to one counsellor, parents will bring along their children for family counselling session when they are unable to control and monitor their children's behaviour.

Just being lazy...some are wild... wild means...they lied...like going to a tuitionclass...from primary school to secondary school, there are the criteria...going to a tuition class but going to a shopping complex, cyber café... some of them are standard 6 , form 1 ...but the mother brought him along since he was standard 5 . He is what people called beggar, stubborn and wild...love bite was found when he returned home...love bite

Drug addiction and smoking are infamous issues that have been terrorising families and societies in Malaysia for a long time. In this study, family counselling received cases of children with drug and smoking problems in accordance to the out of control children act 2001. The involved children with such problems are mostly caught by the authorities and sent to Social Welfare Department. These kids are convicted with the 2001 act and their cases are handled by the relevant officers and counsellors (under family counselling). This issue has been explained by the counsellor on duty at Social Welfare Department.

The Paroi case...most cases involving drugs, 'horse' pills, and others related to those

Therefore, in this study of family counselling, there are a lot of issues related to children and their negative 
attitudes which jeopardize the harmony of the family. Children are portrayed as the individuals that need help in making behavioural changes in order for the family to function well.

\subsection{Family Involvement in Family Counselling}

High commitment of family involvement is much needed in family counselling. This is because family counselling differs from individual counselling whereby in family counselling the presence and commitment of all family members are required and sometimes even involving the grandparents and other relatives (according to the participants of the study). The distance of the counselling centre is one of the issues brought up by the families when it comes to their commitment in attending a family counselling session.

Thank god it is nearby...it's UiTMLendu...quite near to process..because he's near...easy...if he's in UM..UUM...maybedifficult...due to travelling...takestime...this is not difficult...because he's in ITM Lendu...near...he can run to one class or two just like that...maybe easy

When the distance between counselling centre and the child's learning institution is near, it is possible for the child to attend the family counselling session.

Meanwhile, the family's understanding on counselling is also an issue shared by the participants. When the family understands the concept of counselling even a bit, they will give commitment in the family counselling process. The participants commented that the family's level of understanding relates to their education level. Their education level can be a measurement of family's involvement and commitment, hence a family with good academic background will understand the need of family counselling for them and easy to cooperate with the counsellor.

He has good academic background, thinks well and open minded...so educated family when they have exposure on family counselling....about family counselling or heard any useful info he might come...because he understands that service to help and counsellor..can attach with everything without extra time and can listen to each other...easy for discussion to happen.

\subsection{Counsellor's Competency in Family Counselling.}

In the study, all participants admitted that counsellors who handle family counselling must have high level of competency. This is becuase helping a conflicted family is a challenge. Every family has their own conflict and story in their daily life routines and the cause that ruins their harmonious life. Thus, the participants think that a family counsellor must have the knowledge, language, networking, interest, habits, experience and profesionalism in family counselling.

The first challenge is knowledge...okay...if the counsellor does not have enough knowledge in doing family counselling...maybe in the form of individual counselling...family counselling is different...secondly is skills...variety of skills to get closer to the family systematically and the skills to approach the sub system of each individual in that family...maybe the first child is talkative...the third one is quiet...so counsellor must have skills to give room to the family members or other sub systems who come...

In the study, the counsellors admitted that they are lacking in terms of the necessary education and training in family counselling. One of them said that family counselling is just a subject with 3 credit hours. He added by saying that family counselling should be offered as a course so that they will have wide knowledge on the field and master it well.

I think like in the university, there is none except general counselling like in USIM, really learn about family counselling because I think this is needed because usually in year 2 there is a paper with 3 credit hours and it is not enough, because we are taught in individual counselling but we need to have other approaches in family counselling because for individual counselling we will focus on one person only..about his feeling. But in family, what about each family member? Because if we talk like that, a family member might be isolated without realizing it. So it is important to have a specialised family counselling. So I think a special paper, not just a paper that covers all...not enough...

According to the counsellors in this study, lack of education and training leads to lack of knowledge. As a result, they are not confident in handling family counselling and at a wit's end. For those who are new and lack of experience, they also admitted that they are not confident in handling family counselling especially facing families with critical conflict.

...because I used to have no skill at all...when we come both parties...quarrelling in the room and we don't know which side to listen to... because they are really angry... 


\subsection{Use of Individual Counselling Theories}

In the study, there are four approaches of individual counselling: Gestalt approach, REBT, Reality and Transactional. Out of 12 counsellors, only 2 of them did not use any individual theries for the individual counselling.

The most popular theory among the counsellors is the REBT theory as in handling family counselling. Generally, the theory is chosen because they believe that harmony of the family is shaken when there is a family member with irrational thinking. Thus all practicioners explained that when this theory is used for the family, the family will think rationally and emotional stability will occur resulting a happy family.

If not, I like to use REBT...because there are few things...in some cases the husband feels he should be respected and when the wife wants to express an opinion, he feels she is against him. And we will say in certain situation, do you agree? Are you happy?...sometimes, the husband is too defensive and if challenge him, he will get angry. So we will use the scale to measure his anger and see what ticks him off? So we will know how serious he is...

The result findings show that the Reality approach is used by three of the counsellors in the study. The focus of the theory is the basic human needs especially love. Love in a family is vital and must exist for the harmony of the family. This theory is able to make the family to focus in the future and leave the past.

Some of them I use the reality theraphy theory...basic need, if we...for example love, belonging, such as if we love our wife...what to do...if we love a lot... what will happen...because for me in my family I would stress my love when I say hi...say hi with love...speak with love...feel it...cook...cook with love...so we will really into it until we don't have the heart to betray to lie to do bad things...especially basic need and counsellor has many roles here, must have sense of humour, not too much...must have some...sometimes the client is too serious we need sense of humour...joke a bit...he will not feel so stressed so he will open up a bit, wants to share...

Transactional theory is also used by the counsellors because they think the problems in the family are caused by communication factor between the parents and the children. The counsellors think when the miscommunication happens in the family, it is easier to use the theory in helping the family in family counselling. For them, TA provides an easy path to understand the miscommunication in the family.

Sometimes we consider the communication and transactional part...we show, if the parents say like this, how the children respond? From that, we can see, there is miscommunication...for communication I like to use transactional...easy to see...

Lastly, the Gestalt theory is used by one of the counsellors. According to him, the theory is used in family counselling, for divorce cases in particular. For him, the theory is able to help him handling family counselling with divorce issues.

There are divorce cases...I use gestalt...

\section{Discussion}

The study shows that families in Malaysia will only get counselling service when the situation has become critical. For example, when the children have illegitimate pregnancy, involve in drugs and play truancy. This shows that Malaysians do not have the awareness about the importance of family counselling as a preventive measure. Lew and Bettner (1999) stated that a family does not only need family counselling when there is a critical problem, but also for the small problems like unable to mould positive attitude for a family member. Although it might be only a member of the family, the impact on the whole family is huge. Even when the family shows lack of support, less friendly, less emotional support, less communication with the children, most kids will show problematic attitude (Santisteban, 1997).

Family is the dominant aspect in family counselling of this study. All counsellors expressed the same opinion that family counselling process will be carried out with success when the family gives high commitment in the session. When the family is committed, it is easier for the counsellors to help every single member of the family (Kaplan, 2003). A study done by Holtzworth-Munroe et al. (1989) supported this finding by stating that a success in family counselling depends on the involvement and determination of the family in therapy. Even the level of education, family cohesion, ability to express feelings are the factors that influence the family counselling process and this supports the findings of a study done by (Patterson 2009).

Education, training, knowledge and experience are vital aspects contributing to the competency of the counsellors. The research findings show that education and training are the most challenging criteria for the counsellors. The participants of this study admitted that the education and training in their degree and master studies are not sufficient for them to handle counselling process efficiently. Based on the syllabus at all local 
universities, USIM is the only university that offers family counselling as a course at postgraduate level. However there is no USIM graduate in this study as USIM graduates have just graduated and are not yet placed in any government sector. The interviewed practicioners admitted that they used the basic skills in individual counselling. None of them uses techniques like circular questioning which should be used in family counselling (Patterson, 2009).

The study shows that new practicioners (with less of 5 years' experience) are not confident in handling family counselling process if compared to those who have more years of experience. Patterson (2009) stated that experienced counsellors have a lot of information, integrated the information in actual family counselling and have good instinct. According to him, family counsellors need 1000 to 1500 hours of practice session in order to have the confidence in handling family counselling process.

The study shows that practicioners with postgraduate qualification (master level) and at least took a subject in family counselling will be more knowledgeable and competent in handling a session. This finding supports the past studies that say counsellors must have social and cultural knowledge on a society (Santisteban et al., 1997). In Iran, the family counsellors must have the academic credentials at master and doctorate level with the license produced by the government (Khodayarifard et al., 2007).

Therefore, future family counsellors must have suitable training. Otherwise, they will not use the family system as intervention and more proned to use the individual system for the family (Graves et al., 2009). Patterson (2009) also highlighted on the knowledge of family counselling as there are counsellors who still wonder what to do with the family, what theory to use, which technique is suitable for the family and which intervention can be used to help in achieving the family's goals.

In accordance to the studies done in the West, the aspects of the practicioners are the driving force behind a good family counselling process. The required aspects are knowledge, personality, relationship, language, frequent sessions and professionalism as recognized in this study, similar result to the studies done outside Malaysia. Practicioners with competency in terms of knowledge (Kaplan, 2003), fluent in language (Perkin-Dock, 2005; Odell et al., 1994), easy going personality (Kaplan, 2003), a lot of experience (Kaplan, 2003) and high level of professionalism will guarantee a sucessful family counselling practice (Sporaowski, 1995).

Knowledge is the key factor behind a successful practice of family counselling. A family counsellor must have knowledge on various fields like law, Islamic law on wealth and family, psychology and human development. In the study, the practicioners reported that family Islamic law is a must because in some cases they are required to handle divorce cases in family. The findings supported the study of Rozman et al. (2003) which found that things dealing with family issues in Islam are needed in dealing with couples who want a divorce. Roszlina (2000) also stated that family negotiators or the counsellors in Islamic law sector must have the knowledge of family law besides the religious and counselling skills. They will assist in terms of explaining the rights after a divorce happens.

Moreover, the practicioners reported that knowledge in counselling such as skills, approaches and communication is important in ensuring the family counselling process goes well and efficiently. Holtzworth-Munroe et al. (1989) mentioned that counsellors must have 4 skills: (i) have active role and able to direct in counselling session, (ii) encourage changes, (iii) teach family and instill hope and (iv) provide natural emotionto the family.

In addition, the findings show that frequency in handling session and experience are vital aspects in family counselling practice. The findings support Kaplan's (2003) study that emphasizes the counsellors with knowledge, personality, interest, frequency in handling session and experience can influence the family counselling process. The participants in this study agreed that experience in handling family counselling is vital whereby at the beginning they do not have the self-confidence, yet the situation changes when their experience increases after working for more than 3 years. The findings also support the study of Strozier et al. (2005) which points out the not so experienced counsellors face difficulties in handling family counselling especially cases that involved court order. According to Strozier (2005), there are two factors that make an experienced counsellor capable in handling family counselling: (i) non experienced counsellors are worried and able to handle family counselling well and systematically, (ii) experienced counsellors have many techniques, procedures and able to develop good bond with the family.

This study shows that future challenges from the family will be cooperation and involvement of the family, their attitude, financial problems, education and demographic background. When the family has less faith and understanding in the counselling process, the process will not go well.Chen et al. (2001) said that clients with less psychological awareness, having bad psychological problems and less faith in the relationship with the 
counsellor will need a long time to make changes in the counselling session.

High defensive attitude especially the head of the family (the father) will make things difficult for the counsellors. This is because cooperation from the family members is needed in analysing, evaluating and creating suitable intervention for the family issues. This study clearly shows that the father is the member in the family with poor attendance rate and against the family counselling process. This is similar to the study of Frieman (1994) in the US which stated that the father has the difficulty in attending the family counselling especially when it comes to divorce cases. He pointed out that counsellors must have strategies in hand to persuade the father to get involved in the counselling process. The strategies are sending all the information about the children at school to both separated parents, making it compulsory for the father to help the children with their homework and attend parenting seminars plus preventing the children being trapped in parents' conflict.

\section{References}

Ahmad, W. A. K. W. (2007). Model of counseling Community and solution. Counseling Workshop 24. Social Scinces Faculty. The National University of Malaysia.

Al, M., \& Cathleen, K. K. (2002). Four phases of Adelerian counseling: Family resilience in action. The Journal of Invidual Psychology, 58(3), 225-234.

Carson, J., Sperry, L., \& Lewis, A. J. (2005). Family therapy technique-intergrating and tailoring treatment. New York: Routledge Talylor \& Francis Group.

Chen, P., Tsai, S., \& Lai, N. (2001). The constructon of a process-change model of unmet expectiation based on the Satir model. Asian Journal of Counseling, 8(1).

Childers, H. J. (1998). An exploratory study of the termination process in marriage and family therapy (Unpublished master's thesis). Family and Human Development.

Creswell, J. W. (2002). Educational research-planning, conducting, and evaluating quantitative and qualitative research (2nd ed.). New Jersey: Person Merril Prentice Hall.

Everts, J. F. (1994). Developing family services in Malaysia. Journal Psikologi, 9, 23-33.

Fenell, L. D., \& Weinhold, K. B. (1997). Counseling families an introduction to marriage and family therapy (2nd ed.). Denver: Love Publishing Company.

Frieman, B. B. (1994). Children of divorced parents: Action steps for the counselor to involve father. Elementary School Guidance \& Counseling, 28(3).

Ghani, S. A. (2004). The effectiveness of family counseling on family adaptation cohesion family, family environment, delinquent behavior and early adolescent self-concept (Unpbilished doctoral dissertation). Social Scinces Faculty, The National University of Malaysia

Halstead, W. R., Linda, D., Wagner, L. D., Vivero, M., \& Ferkol, W. (2002). Counselors' Conceptualization of caring in the counseling relationship. Counseling and Value, 47(1), 37-47. http://dx.doi.org/10.1002/j.2161-007X.2002.tb00222.x

Herbert, J. T. (1989). Assessing the need for family therapy: A primer for rehabilitation counselors. Journal of Rehabilitation, 55(1), 45-51.

Ismail, R. (2002). Family counseling and marriage: A method to facing the challenges. Sabah: Penerbit Universiti Malaysia Sabah.

Kaplan, D. N. (2003). Family counseling for all counselor. ERIC Clearinghouse on Counseling and Student Services. CAPS Publications

Keith, D. M. (2001). Structural-strategic family counseling: A case study in elementary school counseling. Professional School Counseling, 4(3), 180-186.

Odell, M., \& Quinn, W. H. (1998). Therapist and client behaviors in the first interview: Effects on session impact and teatment duration. Journal of Marital \& Family Therapy, 24(3), 369-388. http://dx.doi.org/10.1111/j.1752-0606.1998.tb01091.x

Patterson, J., Williams, L., \& Edwards, T. M. (2009). Essential skill in family therapy: From the first interview to termination (2nd ed.). New York: The Guilford Press.

Petrocelli, J. V. (2002). Processes and stages of change : Counseling with the transtheoretical model of change. Journal of Counseling \& Development, 80(1), 22-30. http://dx.doi.org/10.1002/j.1556-6678.2002.tb00162.x 
Pinsof, W. M. (1989). A conceptual framework and methodological criteria for family therapy process research. Journal of Consulting and Cilinical Psychology, 57(1), 53-59.

Rosazlina, M. (2000). The effectiveness family counseling center in dealing divorce problem: Case study in K. Terengganu (Unpublish thesis, Department of Syariah, Islamic of Academic Malaya Universiti).

Rozman. (2003). The need of analysis for counseling approach to the divorce problem: Case study in Center of Religion Johor. Conference of National Islamic Counseling. Universiti Utara Malaysia.

Salim, S. (2006). The role of counseling in dealing with the problems and build family well-being. In A. R. A. Rashid, S. Hussin, \& J. Tubah (Eds.), Family institute face the challenges new millenium (pp. 44-52). Kuala Lumpur: Utusan Publication \& Distributors Sdn. Bhd.

Stinchfield, T. C. (2004). Clinical competencies spesific to family based therapy. Counselor Education \& Supervision, 43(4), 286-300. http://dx.doi.org/10.1002/j.1556-6978.2004.tb01853.x

Waehler, C. A., \& Lenox, R. A. (1994). A concurrent (versus stage) model for conceptualizing and representing the counseling process. Journal of Counseling \& Development, 73(1), 17-22. http://dx.doi.org/10.1002/j.1556-6676.1994.tb01704.x

\section{Copyrights}

Copyright for this article is retained by the author(s), with first publication rights granted to the journal.

This is an open-access article distributed under the terms and conditions of the Creative Commons Attribution license (http://creativecommons.org/licenses/by/3.0/). 